\title{
Large-Area Crystalline Silicon Solar Cell Using Novel Antireflective Nanoabsorber Texturing Surface by Multihollow Cathode Plasma System and Spin-On Doping
}

\author{
Utpal Gangopadhyay, Sukhendu Jana, and Sayan Das \\ Sponsored Research Laboratory, Meghnad Saha Institute of Technology, Kolkata 700150, India \\ Correspondence should be addressed to Utpal Gangopadhyay; utpal_ganguly@yahoo.com
}

Received 12 December 2012; Accepted 20 January 2013

Academic Editors: K. A. Kavadias, V. Makareviciene, and M. Souliotis

Copyright (C) 2013 Utpal Gangopadhyay et al. This is an open access article distributed under the Creative Commons Attribution License, which permits unrestricted use, distribution, and reproduction in any medium, provided the original work is properly cited.

\begin{abstract}
We present $11.7 \%$ efficient p-type crystalline silicon solar cells with a nanoscale textured surface and no dielectric antireflection coating. We propose nanocrystalline-like textured surface consisting of nanocrystalline columnar structures of diameters from 50 to $100 \mathrm{~nm}$ and depth of about $500 \mathrm{~nm}$ formed by reactive-ion etching (RIE) in multihollow cathode system. This novel nano textured surface acts as an antireflective absorbing surface of c-Si abbreviate as ARNAB (antireflective nanoabsorber). Light shining on the surface of RIE-etched silicon bounces back and forth between the spikes in such a way that most of it never comes back. Radio frequency (RF) hollow cathode discharge allows an improvement of plasma density by an order of magnitude in comparison to standard RF parallel-plate discharge. Desirable black silicon layer has been achieved when RF power of about 20 Watt per one hollow cathode glow is applied for our multihollow cathode system. The RF power frequency was $13.56 \mathrm{MHz}$. The antireflection property of ARNAB textured surface has been investigated and compared with wet-textured and PECVD coated silicon samples. Solar cell using low-cost spin-on coating technique has been demonstrated in this paper. We have successfully achieved $11.7 \%$ efficient large area $\left(98 \mathrm{~cm}^{2}\right)$ ARNAB textured crystalline silicon solar cell using low-cost spin-on coating (SOD) doping.
\end{abstract}

\section{Introduction}

Surface texturization is usually promoted to enhance the light absorption in silicon solar cells [1]. Wet anisotropic chemical etching technique used to form random pyramidal structure on $\langle 100\rangle$ mono-crystalline silicon wafers usually is not effective in texturing of low-cost multicrystalline silicon wafers because of random orientation nature. The quality of lower cost multicrystalline silicon (mc-Si) solar cell performance is close to that of monocrystalline solar cell, with the major difference resulting from the inability to texture mc$\mathrm{Si}$ surface. Expensive antireflection layers like silicon nitride and magnesium fluoride have been applied to $\mathrm{mc}-\mathrm{Si}$ solar cells front surface to reduce light reflection. Recently, various forms of surface texturing approach have been applied to mc-Si surface including laser structuring [2], mechanical diamond saw cutting [3], porous-Si etching [4-7], photolithographically defined etching [8], and reactive-ion etching (RIE) method [9]. From the Sandia report (S. H. Zaidi,
SAND2000-0919, Sandia contract \#BE-8229, April 2000), it is evident that different gas mixture can be used for fabrication of nanotextured silicon surfaces. Jansen et al. [10] reported on a black silicon method in planar parallel-plate system reactors for $\mathrm{SF}_{6} / \mathrm{CHF}_{3} / \mathrm{O}_{2}$ plasma. Only $\mathrm{SF}_{6} / \mathrm{O}_{2}$ plasma chemistry was sufficient to have antireflective nanoabsorber textured surface looks black surfaces. In the $\mathrm{SF}_{6} / \mathrm{O}_{2}$ plasma, $\mathrm{SF}_{6}$ is the source of active fluorine that etches silicon and $\mathrm{O}_{2}$ supply oxygen radicals that passivate the surface of the etched silicon structures. The microstructures consist of a silicon body with a thin passivating siliconoxyfluoride skin. The origin of micromasks on the top of the etched silicon structures is caused by the silicon surface contaminations. An extensive study of $\mathrm{SF}_{6} / \mathrm{O}_{2}$ RIE in parallel-plate reactors was done by Sandia group [11] for silicon solar cell application. Different shapes of etched microstructures were observed. When a certain balance between the etching and the passivation was found, nearly vertical walls of the structures were obtained. Special technique received a patent support for sputtering 


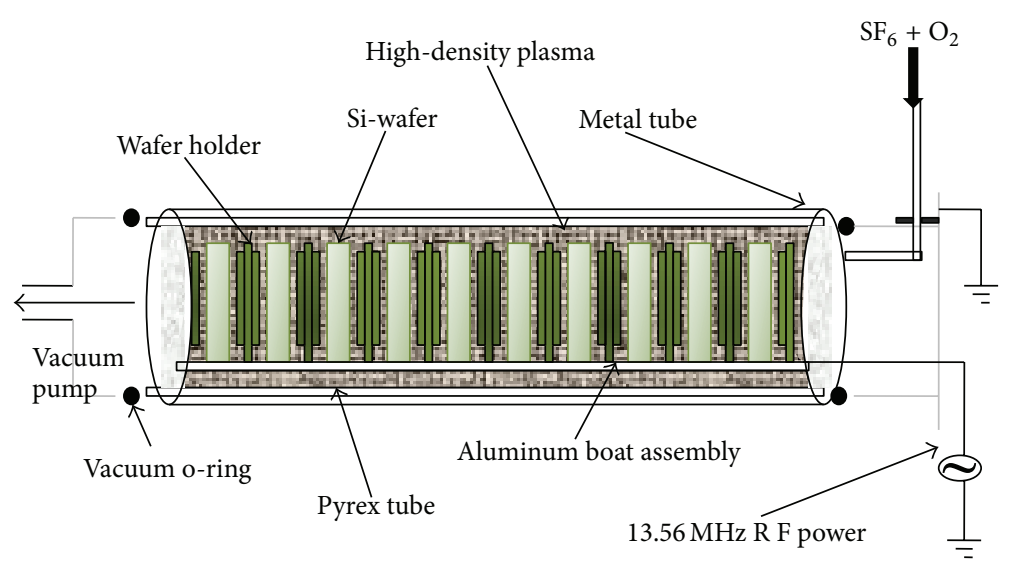

FIGURE 1: Schematic diagram of proposed multihollow cathode system.

metal contaminations on the surface so-called metal-catalyst approach [12]. Some research work related to the black silicon solar cell was already reported elsewhere but their experimental conditions and processes were different [13-15]. NREL previously had demonstrated that their nanostructures reflected less light than the best antireflection layers of a solar cell. But until now, they had not been able to achieve overall efficiency with their black silicon cells that could approach the best marks for other silicon cells. Oh, Yuan, and Branz first had to determine why the increased surface area of the nanostructures dramatically reduced the collection of electricity and hurt the voltage and current of the cells [16].

Possibility of other types of reactors to produce the antireflective nanoabsorber textured silicon surfaces is very important. We are reporting about the possibility to obtain antireflective nanoabsorber (ARNAB) textured surface in a RF multihollow cathode discharge. Due to the low-voltage operating characteristics, RIE in RF multihollow cathode system produces lower plasma-induced damage to silicon than that of the conventional RF diode plasma systems. Multielectrode embodiment makes our RF multihollow cathode system adapt to a high-production environment.

In this paper, we have reported the formation of uniform antireflective nanoabsorber (ARNAB) texturing silicon surface on crystalline silicon (c-Si) using RF multihollow cathode system. We have also reported the fabrication of ARNAB texture c-Si solar cells using a low-cost spin-on doping (SOD) technique.

\section{Experimental}

2.1. Multihollow Cathode Reactor. The Multihollow cathode reactor used in our experiment for ARNAB textured etching of $\mathrm{c}-\mathrm{Si}$ is shown in Figure 1 . The hollow cathode reactor consists of a Pyrex tube, defining the vacuum chamber, with a grounded metal cylindrical electrode outside acting as a counter electrode for an assembly of powered aluminum electrodes which are in electrical contact with silicon wafers. The last plate electrodes have diameters of $150 \mathrm{~mm}$. The electrodes are electrically and structurally connected by metal supports close to their outer rim to have separation of the electrodes equal to $25 \mathrm{~mm}$. The Pyrex tube has inside diameter equal to $190 \mathrm{~mm}$. Applied RF power creates electrical field at each powered electrode surface causing excitation of reactive gases in spaces preferably between the silicon wafers to produce a high level of ionization of the gas and dense plasma therein.

These dense plasma regions are obtained by means of repelling movement of entrapped electrons between the powered electrodes, so-called hollow cathode effect [17]. Uniform micromasks disposition on the silicon surface is a necessary condition for uniform texturing. The origin of micromasks in our case may be the result of resputtering of both the aluminum electrodes and the Pyrex tube. Initially, we have taken $1-5 \mathrm{ohm} \cdot \mathrm{cm},\langle 100\rangle$, p-type 350 -micron-thick as-cut mc-Si wafers as a starting material. Before ARNAB textured etching, we have textured mc-Si wafer by conventional $\mathrm{NaOH}-\mathrm{IPA}$ texturing.

Plasma etching process was developed that used $\mathrm{SF}_{6} / \mathrm{O}_{2}$ mixtures to produce a randomly textured silicon surface which looks black to naked eye. The silicon surface is covered by a lot of columnar microstructures to have this property. Desirable texturing result was achieved when RF power of about $20 \mathrm{~W}$ per one hollow cathode glow is applied for our multihollow cathode reactor. RF power frequency was 13.56 MHz. The $\mathrm{SF}_{6} / \mathrm{O}_{2}$ partial pressure ratio was 2.5 and the etching pressure was 50 mTorr for plasma glowing conditions. The texturing time was $20 \mathrm{~min}$. After ARNAB textured etching using multihollow cathode plasma system, the textured surface looks like a black surface.

We have investigated random texturing of $\mathrm{Si}$ aimed at reducing Si reflection in the visible IR spectral regions by UVVIS-NIR spectrophotometer.

\subsection{Fabrication of RIE ARNAB Textured Crystalline Silicon} Solar Cell. In this experiment a phosphosilicate film was used as the SOD source for diffusion. SOD phosphosilica film was coated on front surface of the ARNAB textured silicon surface by spinning technique followed by thermal baking in a hotair oven. Wafers were then annealed in IR furnace at $855^{\circ} \mathrm{C}$ for 2 min followed by 1 hour cooling in presence of $\mathrm{N}_{2}$ and $\mathrm{O}_{2}$ gas ambience. The IR furnace temperature profile during SOD has been given in Table 1 . The optimized sheet resistance of the SOD doping on RIE ARNAB textured surface is $60 \Omega / \square$. 
TABLE 1: Parameters of a typical IR furnace SOD diffusion.

\begin{tabular}{|c|c|c|c|c|c|c|}
\hline \multicolumn{2}{|c|}{ Heating cycle in sec. } & \multicolumn{2}{|c|}{ Cooling cycle in sec. } & Plateau temp. and time & $\mathrm{N}_{2}$ flow $\mathrm{cc} / \mathrm{min}$ & $\mathrm{O}_{2}$ flow $\mathrm{cc} / \mathrm{min}$ \\
\hline $\begin{array}{l}50 \text { to } 684^{\circ} \mathrm{C} \\
120\end{array}$ & $\begin{array}{c}684 \text { to } 800^{\circ} \mathrm{C} \\
60\end{array}$ & $\begin{array}{c}800 \text { to } 500^{\circ} \mathrm{C} \\
120\end{array}$ & $\begin{array}{c}500 \text { to } 100^{\circ} \mathrm{C} \\
180\end{array}$ & $800^{\circ} \mathrm{C}$ and $180 \mathrm{sec}$ & 100 & 50 \\
\hline
\end{tabular}

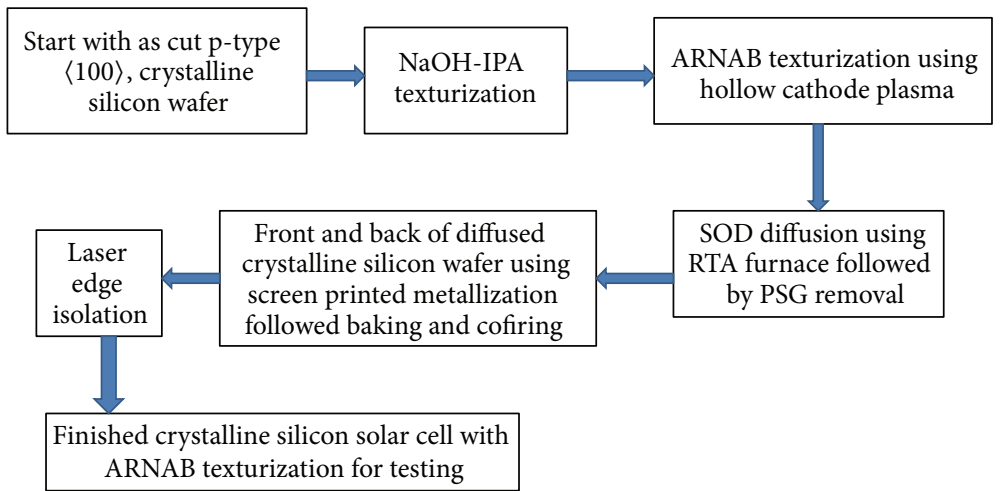

FIGURE 2: Flow chart for fabrication of ARNAB c-Si solar cells using SOD diffusion.

After diffusion, the residual silica film was removed by dilute HF solution. The edge isolation of all diffused wafers was carried out using standard coin-stacking and wet-etching technique. The back and front metallization of the diffused black silicon wafers were carried out using standard Al-paste and Ag-paste screen printed metallization technique followed by baking and cofiring at temperature of $715^{\circ} \mathrm{C}$ in a conveyer belt furnace. The detailed flow chart for fabrication of RIE ARNAB textured c-Si solar cell using SOD diffusion is shown in Figure 2.

\section{Results and Discussion}

We have carried out scanning electron microscope (SEM) investigation of these randomly ARNAB textured etched silicon surfaces. From the SEM micrograph Figure 3, we have found that the ARNAB textured silicon surface is the silicon surface covered by a lot of columnar microstructures. The columnar microstructures have diameters from 50 to $100 \mathrm{~nm}$ and depth of about $500 \mathrm{~nm}$. The region of technological conditions was very narrow to have good uniformity for large-area silicon surface looking all most black. The sidewall passivation of etched columns with silicon oxide is very sensitive to oxygen content at the silicon surface. Any deficiency of oxygen was a main cause of changing from black surface to polished one.

Moreover in our hollow cathode system, RF hollow cathode discharge allows an improvement of plasma density by an order of magnitude in comparison to standard RF parallel-plate discharge. The increase in the plasma density has been achieved with the hollow cathode configuration and it is attributed to the so-called "electron mirror" effect, in which a negative self-developed bias voltage on the two opposing RF powered electrodes helps to increase the density of the high-energy electrons (responsible for ionization) and to also reduce their recombination rate.

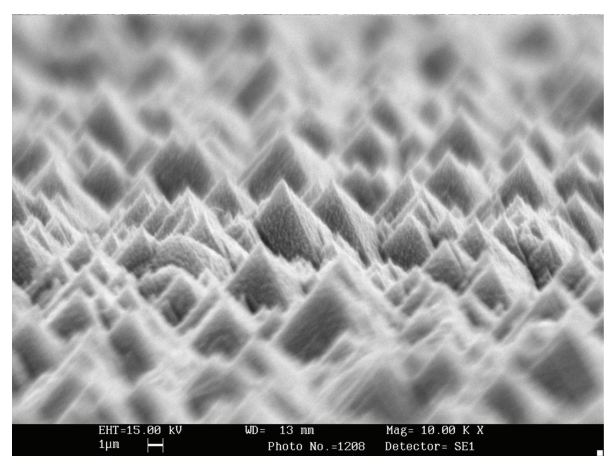

FIGURE 3: SEM photomicrograph of top view of RIE ARNAB textured c-Si surface.

It is also noticed that the hollow cathode effect can be enhanced by appropriate discharge confinement that results in raising plasma density, an increase in the ion flow to the electrodes (substrates), and a decrease in the average ion energy. The electrons have much higher mobility than the ions and they are very easily collected on an electrode whenever it becomes positive with respect to the glow space. This fact, in turn, causes depletion of electrons from the dark space with a consequent rise in potential of the glow space with respect to the electrodes.

Figure 4(a) shows a typical spectral reflectance of ARNAB textured surface compared to $\mathrm{NaOH}-\mathrm{IPA}$ textured with and without $\mathrm{SiN}_{x}$ ARC. We have also carried out spectral reflectance measurement experiment with finished solar cells using aforesaid surface structures as shown in Figure 4(b).

The ARNAB textured c-Si solar cell shows almost no significant reflection in the region from $300 \mathrm{~nm}$ to $1100 \mathrm{~nm}$ wavelength of light compared to PECVD $\mathrm{SiN}_{x}$ AR coated $\mathrm{NaOH}-\mathrm{IPA}$ wet-textured c-Si solar cell. The reflectance characteristic curve of ARNAB textured c-Si solar cell as shown 


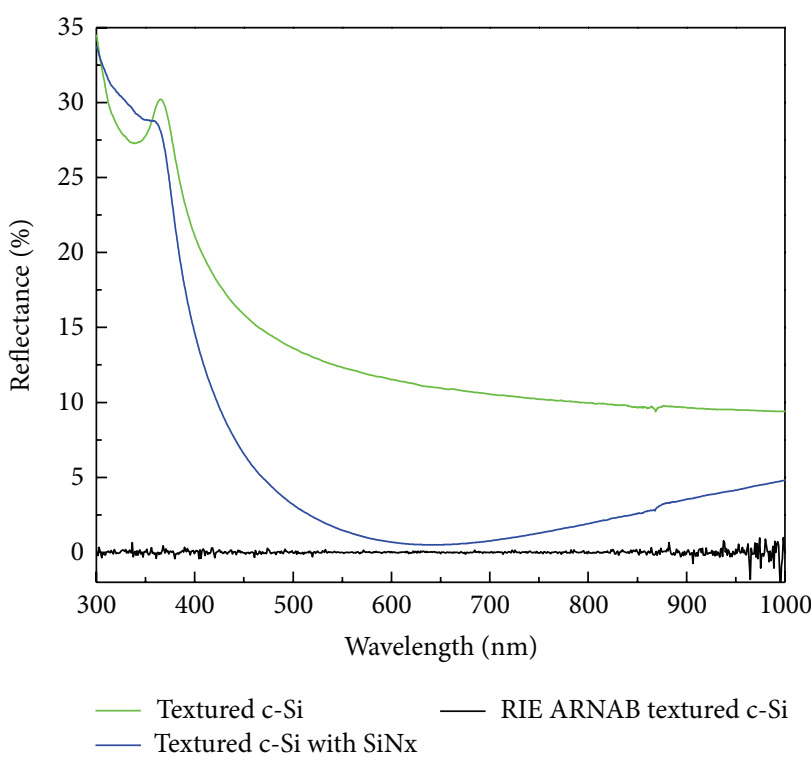

(a)

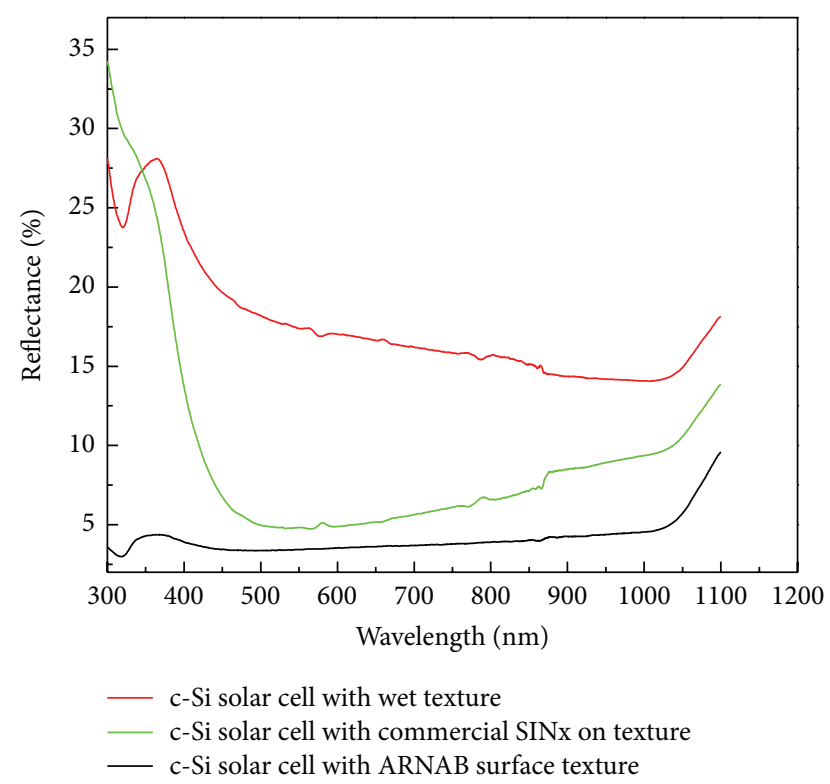

(b)

FIgURE 4: (a) Reflectance of ARNAB textured silicon surface along with PECVD SIN ${ }_{x}$ coated textured surface. (b) Reflectance of ARNAB textured silicon solar cell along with and without PECVD $\operatorname{SIN}_{x}$ coated textured Solar Cells.

in Figure 4(b) indicates the probability of effective increase of carrier generation due to almost nil light reflection from the nanotextured surface. This is one of the important indications to achieve high-efficiency c-Si solar cell fabrication even without addition of $\mathrm{SiN}_{x}$ or $\mathrm{TiO}_{2}$ like high-cost antireflection coating process step and also increase the total throughput rate of overall production process line. The performance of the black silicon solar cells was measured under the standard $100 \mathrm{~mW} / \mathrm{cm}^{2}$ AM1.5 (air mass) global spectrum at $25^{\circ} \mathrm{C}$ and all electrical parameters have been extracted using leastsquare fit of the single silicon solar cell diode model [18] as shown in Table 2.

Light-illuminated current-voltage (LIV) characteristic is shown in Figure 5. From Table 1, we have observed that the efficiency of SOD diffused ARNAB textured c-Si solar cell is around $11.7 \%$.

In our SOD RIE ARNAB textured silicon solar cell experiment, we observed that the open-circuit voltage $\left(V_{\mathrm{oc}}\right)$ and short current $\left(I_{\mathrm{sc}}\right)$ of SOD diffused solar cell is not sufficiently high value as shown in Figure 5 and Table 2. This may be due to the low value of shunt resistance and high series, respectively, as mentioned in Table 2 leading to lower value of fill factor (F.F) and thereby the efficiency of our fabricated SOD diffused RIE textured c-Si solar cell.

Therefore by proper choosing of cofiring temperature, it is possible to enhance the efficiency of SOD diffused ARNAB textured c-Si solar cell up to 18 without any additional ARC. RIE ARNAB textured surface and low-cost spin-on doping diffusion are one of the probable routes for fabrication of large-area high-efficiency c-Si solar cell without addition antireflection coating.
TABLE 2: Electrical parameters of ARNAB textured c-Si Solar Cell.

\begin{tabular}{llc}
\hline $\begin{array}{l}\text { Numbers of } \\
\text { parameters }\end{array}$ & Description of electrical parameters & Value \\
\hline 1 & Open-circuit voltage $\left(V_{\text {oc }}\right)$ in Volt & 0.601 \\
2 & Short-circuit current $\left(I_{\mathrm{sc}}\right)$ in Amp. & 2.899 \\
3 & Voltage at maximum power point $\left(V_{m}\right)$ in & 0.468 \\
& Volt & \\
4 & Current at maximum power point $\left(I_{m}\right)$ in & 2.448 \\
5 & Amp. & \\
6 & Power at maximum power point $\left(P_{m}\right)$ in & 1.148 \\
7 & Watt & 0.658 \\
8 & Fill factor (F.F) & 0.048 \\
9 & Series resistance $\left(R_{s}\right)$ in Ohm & 5.158 \\
\hline
\end{tabular}

\section{Conclusion}

We report the success of RIE ARNAB textured on c-Si sample using multihollow cathode plasma system in this paper. Plasma texturing has been shown to produce almost zero reflectance of ARNAB textured silicon surfaces. Adjusting necessary parameters of our multihollow cathode plasma system can control the submicron feature size successfully produced by this texturing. We have also shown that our novel multihollow cathode plasma system has capability to produce uniform nanostructure silicon-etched surface which has the compatibility with the rest of the solar cell fabrication process. We have successfully achieved $11.7 \%$ efficiency of 


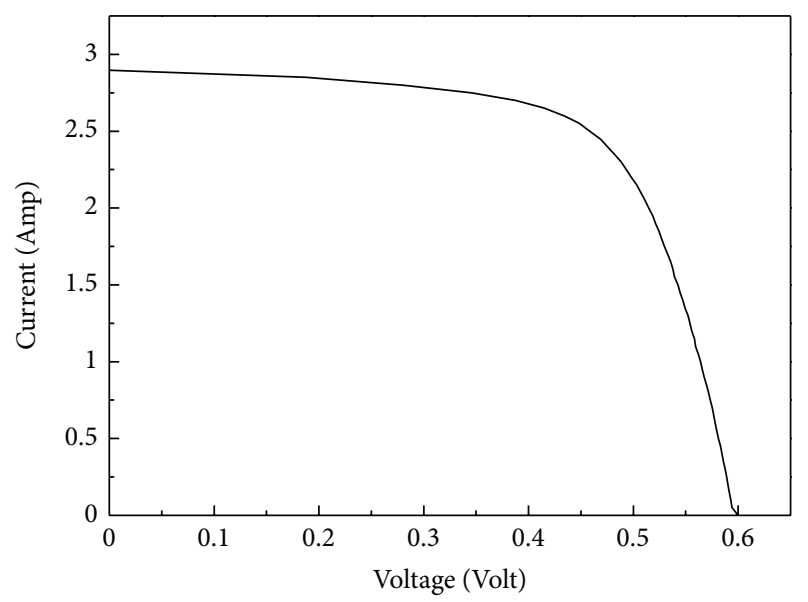

FIGURE 5: Illuminated IV characteristic of $98 \mathrm{~cm}^{2}$ (pseudo-square) ARNAB texture c-Si solar cell using SOD diffusion.

ARNAB textured c-Si solar cell using spin-on doping source and RTP annealing for diffusion. Significant improvement in solar cell performance can be expected in SOD diffused ARNAB textured silicon solar cell by proper choosing belt furnace firing temperature.

\section{Acknowledgments}

This paper is dedicated to the memory of ARNAB, the one and only son of professor (Dr.) U. Gangopadhyay and Lekha Gangopadhyay. The authors would like to thank Meghnad Saha Institute of Technology, TIG, for providing the infrastructural support to carry out research activity in this area. The authors also gratefully acknowledge the DST, Govternment of India for financial support for carrying out solar-cellrelated research activity.

\section{References}

[1] P. Campbell and M. A. Green, "Light trapping properties of pyramidally textured surfaces," Journal of Applied Physics, vol. 62, p. 243, 1987.

[2] S. Narayanan, High efficiency polycrystalline silicon solar cells [Ph.D. thesis], University of New South Wales, Sydney, Australia, 1989.

[3] P. Path, G. Willeke, E. Bucher et al., "Mechanical wafer engineering for high efficiency solar cells: an investigation of the induced surface damage," in Proceedings of the 24th IEEE Photovoltaic Specialists Conference, pp. 1347-1350, 1994.

[4] M. Lipiński, P. Panek, Z. Witek, E. Beltowska, and R. Ciach, "Double porous silicon layer on multi-crystalline Si for photovoltaic application," Solar Energy Materials and Solar Cells, vol. 72, no. 1-4, pp. 271-276, 2002.

[5] R. Guerrero-Lemus, C. Hernández-Rodríguez, F. Ben-Hander, and J. M. Martínez- Duart, "Anodic and optical characterization of stain-etched porous silicon antireflection coatings," Solar Energy Materials and Solar Cells, vol. 72, no. 1-4, p. 495, 2002.

[6] M. Saadoun, H. Ezzaouia, B. Bessaïs, M. F. Boujmil, and R. Bennaceur, "Formation of porous silicon for large-area silicon solar cells: a new method," Solar Energy Materials and Solar Cells, vol. 59, no. 4, pp. 377-385, 1999.
[7] D. Majumdar, S. Chatterjee, M. Dhar, S. K. Dutta, and H. Saha, "Light trapping in layer-transferred quasi-monocrystalline porous silicon solar cell," Solar Energy Materials and Solar Cells, vol. 77, no. 1, pp. 51-64, 2003.

[8] J. Zhao, A. Wang, M. A. Green, and F. Ferrazza, "19.8\% Efficient "honeycomb" textured multicrystalline and $24.4 \%$ monocrystalline silicon solar cells," Applied Physics Letters, vol. 73, no. 14, p. 1991, 1998.

[9] S. Winderbaum, O. Reinhold, and F. Yun, "Reactive ion etching (RIE) as a method for texturing polycrystalline silicon solar cells," Solar Energy Materials and Solar Cells, vol. 46, no. 3, pp. 239-248, 1997.

[10] H. Jansen, M. de Boer, J. Burger, R. Legtenberg, and M. Elwenspoek, "The black silicon method II: the effect of mask material and loading on the reactive ion etching of deep silicon trenches," Microelectronic Engineering, vol. 27, no. 1-4, pp. 475-480, 1995.

[11] D. S. Ruby, W. K. Schubert, J. M. Gee, and S. H. Zaidi, U.S. patent No. 6091021.

[12] D. S. Ruby and S. H. Zaidi, U.S. patent No. 6329296.

[13] S. Koynov, M. S. Brandt, and M. Stutzmann, "Black multi-crystalline silicon solar cells," Physica Status Solidi, vol. 1, no. 2, pp. R53-R55, 2007.

[14] S. Koynov, M. S. Brandt, and M. Stutzmann, "Black nonreflecting silicon surfaces for solar cells," Applied Physics Letters, vol. 88, no. 20, Article ID 203107, 2006.

[15] B. Liu, S. Zhong, J. Liu, Y. Xia, and C. Li, "Silicon nitride film by inline PECVD for black silicon solar cells," International Journal of Photoenergy, vol. 2012, Article ID 971093, 5 pages, 2012.

[16] J. Oh, H.-C. Yuan, and H. M. Branz, "An 18. 2\%-efficient blacksilicon solar cell achieved through control of carrier recombination in nanostructures," Nature Nanotechnology, vol. 7, pp. 743$748,2012$.

[17] C. M. Horwitz, S. M. Rossnagel, J. J. Cuomo, and W. D. Westwood, Eds., Handbook of Plasma Processing Technology, Noyes, Park Ridge, Ill, USA, 1990.

[18] S. K. Dutta, K. Mukhopadhyay, S. Bandyopadhyay, and H. Saha, "An improve technique for the determination of solar cell parameters," Solid State Electronics, vol. 35, pp. 1667-1673, 1992. 


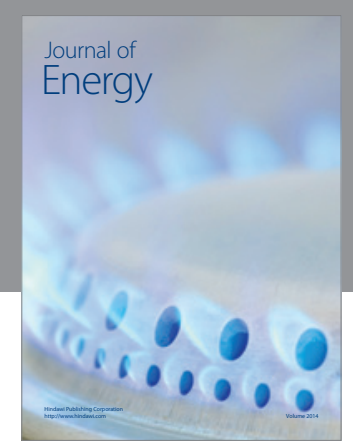

Journal of

Industrial Engineering
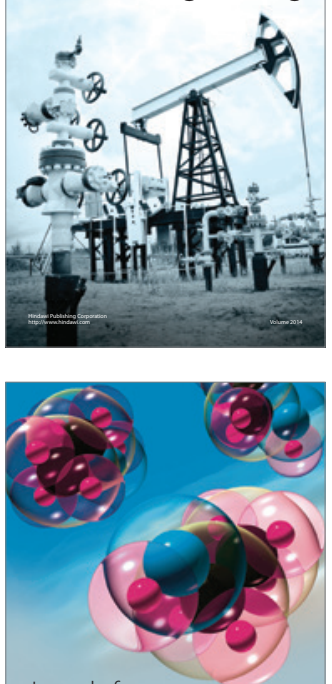

Fuels
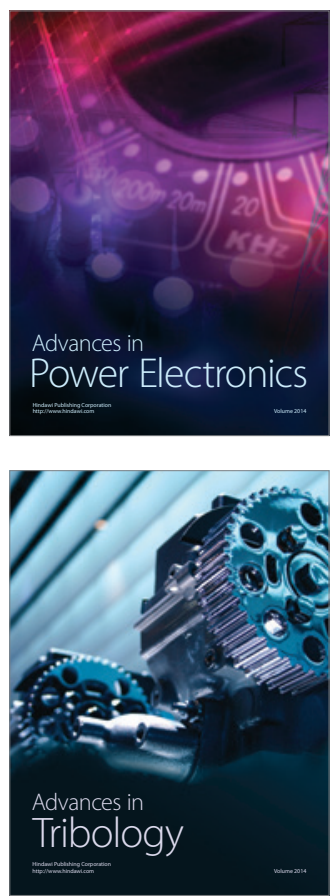

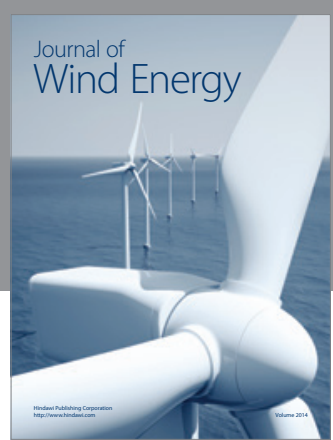

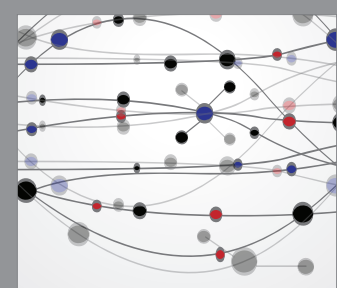

The Scientific World Journal

Submit your manuscripts at http://www.hindawi.com

Journal of

Structures
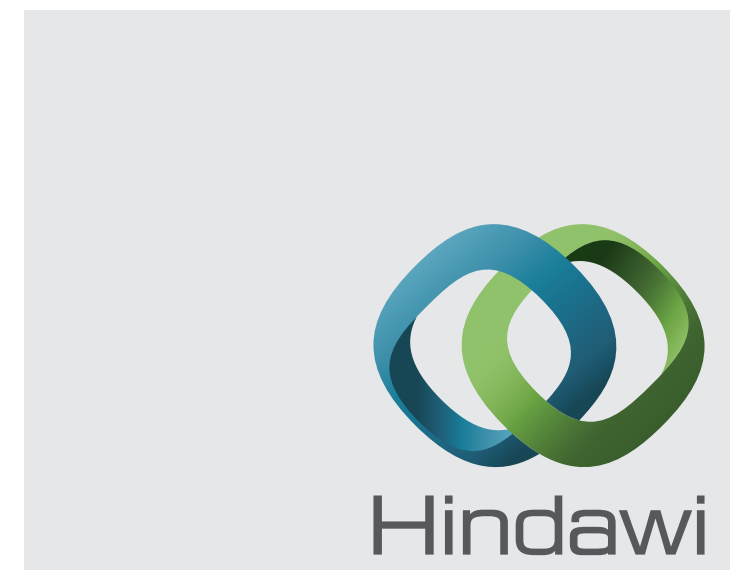

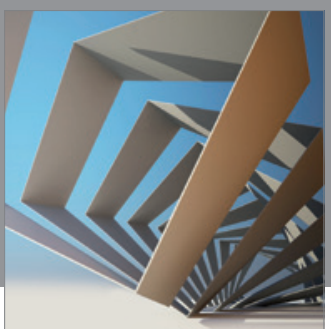

Rotating

Machinery
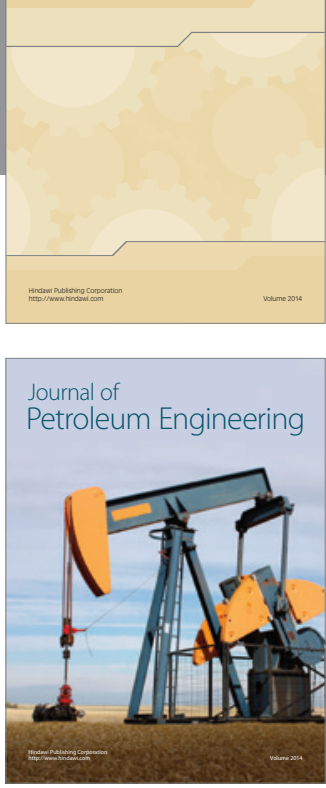

Journal of

Solar Energy
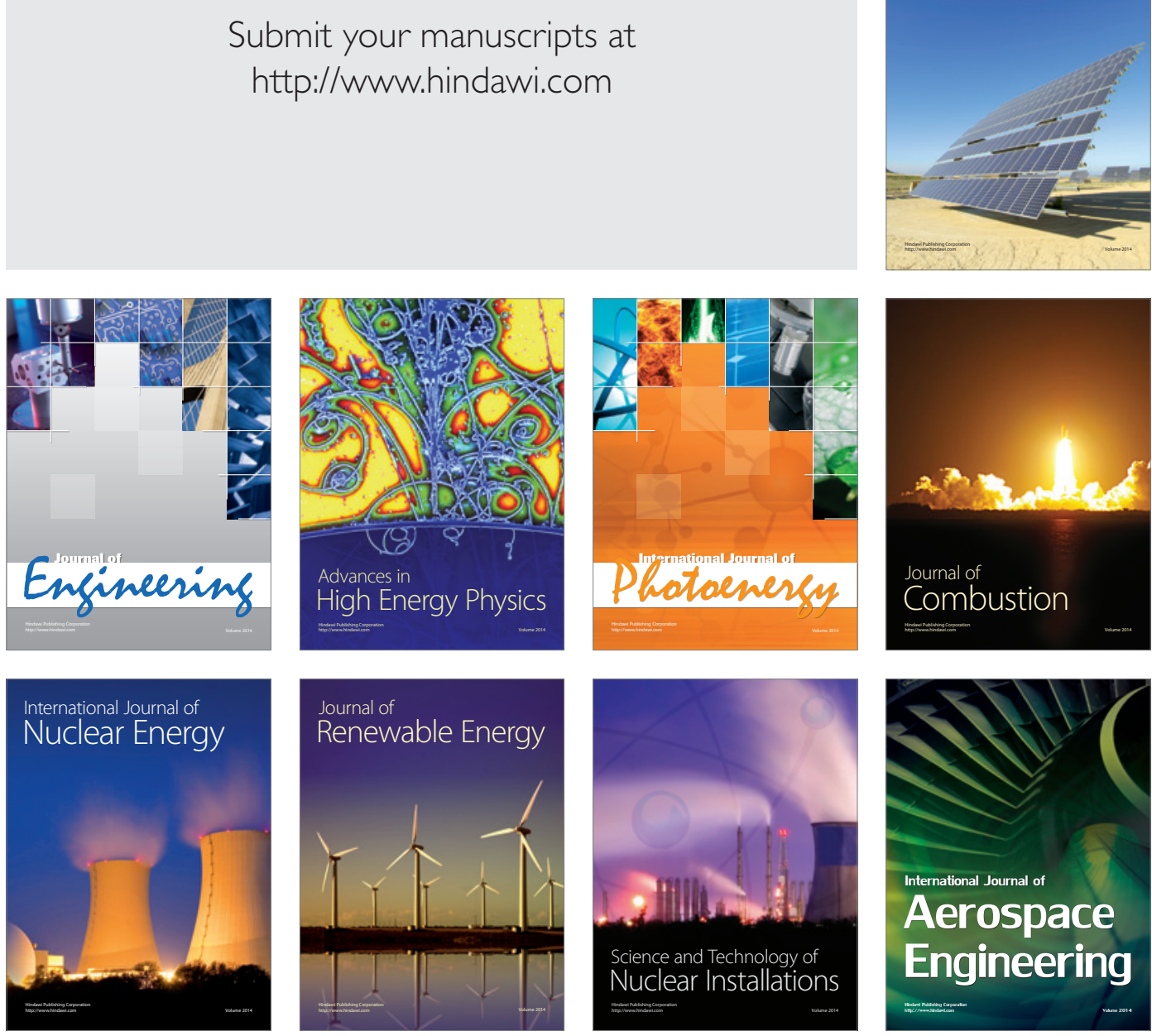